\title{
Principy interpretace na ukázce návrhu venkovní expozice archeoparku Pavlov ${ }^{1}$
}

\author{
Jozef Sedláček, Hana Matějková, Daniel Matějka
}

\section{Interpretation principles on example of proposal for an outdoor exhibition if the Pavlov archeological park}

Abstract: The article deals with the architectural proposal of the outdoor exhibition of Archeopark Pavlov, which is the result of the cooperation of students and tutors of Mendel University in Brno with the Regional Museum in Mikulov and the Archaeological Institute of the Academy of Sciences of the Czech Republic, Brno. The ideas and principles of interpretation of cultural heritage were used in the proposal. The purpose of

1 Článek vznikl na základě podpory při řešení projektu DG18P02OVV018 - Poplužní dvory Čech, Moravy a Slezska a jejich harmonická kulturní Krajina - identifikace a soudobá interpretace kulturních hodnot v rámci Programu na podporu aplikovaného výzkumu a experimentálního vývoje národní a kulturní identity na léta 2016 až 2022 (NAKI II), financovaného Ministerstvem kultury ČR.

2 Tilden, Freeman. Interpreting Our Heritage. Chapel Hill: The University of North Carolina Press, 2008, s. 224.

3 Aldridge, Don. Principles of countryside interpretation and

interpretive planning. Edinburgh: H.M.S.O. for Countryside Commission for Scotland, Countryside Commission, 1975, s. 32. 4 Ham, Sam. Interpretation: making a difference on purpose. Golden Colorado: Fulcrum Publishing, 2013, s. 290.

Ing. Jozef Sedláček, Ph.D. Ústav plánování krajiny, Zahradnická fakulta v Lednici, Mendelova univerzita v Brně jozef.sedlacek@mendelu.cz Ing. Hana Matějková Ústav plánování krajiny, Zahradnická fakulta v Lednici, Mendelova univerzita v Brně hm.naokraji@gmail.com Ing. Daniel Matějka, Ph.D. Ústav plánování krajiny, Zahradnická fakulta v Lednici, Mendelova univerzita v Brně daniel.matejka@mendelu.cz the article is to describe a design process of an outdoor exhibition involving various professional professions - landscaping architect, archaeologist and museum employees. Secondly it describes how the ideas and principles of interpretation of cultural heritage were implemented in the project. The outdoor permanent exhibition is made up of plant design, paving and interactive elements and provides space for experimental and educational activities. Every feature of the exhibition is described in detail and contains a commentary on how to act on the visitor.

Keywords: Archaeology, Landscape Architecture, Outdoor Exhibition, Pavlov

\section{Úvod}

$\mathrm{P}$ ř́padová studie venkovní expozice Archeoparku vznikla ve spolupráci Zahradnické fakulty Mendelovy univerzity $\mathrm{v}$ Brně s Regionálním muzeem v Mikulově (RMM) a Archeologickým ústavem AV ČR, Brno (ARUB). Požadavkem zadání pro venkovní expozici bylo najít takové řešení expozice, které umožní pořádání zážitkového výkladu doprovázeného živými ukázkami, konání workshopů a výzkumný provoz $\mathrm{v}$ experimentální části. Návrh byl zpracován kolektivem studentů krajinářské architektury ve složení Lucie Breuerová, Monika Martišková, Daniel Mašín, Veronika Netolická, Marie Novotná, Daniela Plandorová, Tereza Poláčková pod vedením Ing. Jozefa Sedláčka Ph.D.

Při tvorbě expozice bylo postupováno dle zásad zakladatele interpretace Freemana Tildena, jenž definuje interpretaci jako vzdělávací aktivitu, která odkrývá hlubší smysl a vztahy za pomoci původních objektů, prímé zkušenosti a ilustrativních prostředků. Interpretace je dle Tildena čin- nost, která odhaluje návštěvníkům něco z krásy a kouzla, inspirace a duchovního obsahu, jež leží za tím, co mohou oni sami vnímat svými smysly. ${ }^{2}$ Don Aldridge přináší krátkou, přesto výstižnou definici interpretace: umění vysvětlit význam místa návšstěvnikům s cilem podpořit myšlenku jeho ochrany. ${ }^{3}$

\section{Metody kvalitní interpretace}

Prvním krokem před samotným navrhováním bylo definovat si hlavní sdělení. Podle Hama musí mít kvalitní interpretace silné klíčové sdělení. Toto sdělení následně zjednodušuje př́pravu programu, eliminuje třrištění pozornosti, vytváří logický rámec pro zážitky účastníků a především provokuje $\mathrm{k}$ myšlení, tedy má velkou pravděpodobnost, že návštěvníky osloví. ${ }^{4}$

Hlavní sdělení

Návrh venkovní expozice zdůrazňuje tři poznatky, které by si měl návštěvník z archeoparku odnést. První je, že místo popi- 
suje kulturu gravettienu, která území obývala před 30 tisíci lety. ${ }^{5}$ Druhým poznatkem je, že lovci mamutů neměli jako hlavní zdroj obživy mamuty (ty lovili jen při zvláštních prríležitostech), ale živili se soby a menšími obratlovci. ${ }^{6}$ Třetím poznatkem je, že vzhled krajiny, resp. lokality byl odlišný. Zatímco dnes je lokalita archeoparku jemně modelovaným svahem tvořeným vrstvami spraší o mocnosti několika metrů, pưvodní sídliště bylo situováno na temeni příčného hřbítku tvořeného hrubou vápencovou sutí. Návštěvník by si zde měl uvědomit, že v období před 10-15 tisíci lety, v době trvání poslední doby ledové, došlo k masivní sedimentaci spraší, které přetvořily zdejší krajinu. Dalším poznatkem, který by si návštěvník měl odnést, je, že lovci mamutů nežili $\mathrm{v}$ jeskyních, ale $\mathrm{v}$ otevřené krajině a před nepřízní počasí si budovali jednoduché stany. ${ }^{7}$

\section{Cílová skupina}

Venkovní expozice byla navržena tak, aby byla cílená zejména na rodiny s dětmi. Doplňuje tak vnitřní expozici, která je zaměřena spíš na dospělého návštěvníka.

\section{Požadavky a limity ovlivňující návrh expozice}

Návrh řešení expozice se od začátku musel vypořádávat s omezeními, která představují vlastnické vztahy - expozice je omezena na pozemek ve vlastnictví obce Pavlov a ARUB.

Významným omezením je respektování architektonického výrazu stavby, resp. předpolí stavby, aby nedošlo k zaclonění budovy muzea a krajinné dominanty hradu Děvičky, tyčícího se nad Pavlovem.

Dalším požadavkem definujícím prostorové uspořádání byla skutečnost, že areál musí být uzavíratelný. Z hlediska přírodních podmínek a charakteru místa jsou to zejména mikroklimatické podmínky, a sklon a expozice svahu, které se musely promítnout do výsledného návrhu. Mikroklimatické podmínky jsou extrémně teplé, stanoviště je výsušné, s převážně východní expozicí. Svah je mírný, vypouklý se stejným podélným sklonem, přičemž ve spodní třetině se sklon zvyšuje a pod hranou se vytváří mělká deprese.

\section{Hlavní principy interpretace a popis expozice}

Tilden ve svém díle Interpreting Our Heritage ${ }^{8}$ definoval na základě svého pozorování šest zásad dobré interpretace. Ty byly aplikovány i při tvorbě návrhu expozice:

1) Každá interpretace, která se nevztahuje k jednotlivci, jeho osobnosti nebo životní zkušenosti, bude sterilní.

2) Interpretace není poskytování informací. Jakkoliv každá interpretace obsahuje informace, nepředává je, ale zjevuje. 3) Interpretace je umění, které kombinuje řadu dalších umění. Do jisté míry je možné se mu naučit.

4) Interpretace funguje pomocí provokace, nikoliv instruktáže.

5) Interpretace by měla představovat celek, ne pouze jeho části. Stejně tak by se měla vztahovat k celému člověku - dotknout se co nejvíce smyslů i srdce.

6) Interpretace zaměřená na děti není pouhým zjednodušením interpretace pro dospělé. Řídí se od základů jinými zásadami.

Autoři Beck a Cable doplnili Tildenovy zásady o další principy kvalitní interpretace. Jedním z principů je provokace. Podaří-li se nám v lidech vzbudit otázky, vyprovokovat je k přemýšlení či vytvořit si vlastní názor na dané téma, je to první krok k úspěšné interpretaci. Informace návštěvníkovi pouze předává fakta, zatímco interpretace by se ho měla osobně dotýkat, vyprovokovat ho k aktivitě, probudit jeho fantazii. Druhá zásada je založena na odkrývání nových pohledů na interpretované místo. Podaří-li se nám návštěvníkovi předat nové myšlenky, vhledy, nové pochopení a nahlížení na dané místo z jiného úhlu pohledu, interpretace byla úspěšná. Interpretace musí člověka zasáhnout osobně, musí se protnout s jeho osobní zkušeností, s jeho hodnotami. Abychom to dokázali, musíme vědět, ke komu promlouváme, jaké má životní zkušenosti a zájmy. Jenom tak můžeme dosáhnout
5 Svoboda, Jiří. Dolní Věstonice - Pavlov. Praha: Academia, 2016, s. 399.

6 Ibidem, s. 96-105.

7 Ibidem, s. 55-60.

8 Tilden, Freeman. Interpreting Our Heritage. Chapel Hill: The University of North Carolina Press, 2008, s. 34. 
toho, že návštěvníci budou podporovat naše snahy při ochraně daného území. ${ }^{9}$

Základní esencí působivé a efektivní interpretace je zaujetí pro to, co interpretujeme, i pro lidi, kteří přicházejí, aby s námi toto zaujetí sdíleli. Pro vzbuzení zájmu v návštěvníkovi je potřebné přiblížit dané téma jeho osobním zkušenostem. Návštěvník si hledá svůj vztah a osobní názor na prezentovaná témata. Cílem interpretace není manipulovat návštěvníka nějakým směrem, ale pracovat s ním tak, aby sám došel k určité myšlence, odpovědi či názoru. Interpretace rozvíjí $v$ lidech schopnost a touhu po poznávání krásy jejich okolí, duchovně je pozvedá a podporuje ochranu prírodních a kulturních zdrojü. ${ }^{10}$

Prezentace interpretace je uměním, měla by být představována formou př́iběhů, které informují, baví a pozvedávají. Cílem interpretačního prríběhu je inspirovat a provokovat lidi $\mathrm{k}$ rozšiřování jejich obzorů. Díky př́iběhu se nám podaří vtáhnout návštěvníky do děje, do jiného světa. Existuje několik způsobů, jak vytvořit dobrý príběh. Jedním z tipů je používat příklady - používáme-li konkrétní ilustrace, pomůžeme posluchačům vytvořit si vlastní názor na příběh. Do př́iběhu je také vhodné zapojit vztahy - posluchače zajímají osobní príiběhy. Dalším principem je analogie - pomáhá posluchačům porovnat příběh s něčím, co znají z osobního života. Dobře fungují také přirovnávání pro porovnání charakteristik dvou věcí. Do přiběhu můžete přidat také vaše osobní zkušenosti, které se vztahují k tématu. Další možností je citovat jiné, což osvěží váš prríběh o postřehy ostatních. Humor je dobré používat pro uvolnění atmosféry. Vhodné je opakovat klíčová sdělení, dosáhnete tím zapamatování si důležitých bodů. Do př́běhu je dobré zakomponovat současné události, čímž propojíte prríběh s prrítomností.11

\section{Návrh expozice}

Následující text vysvětluje jednotlivé prvky expozice, které $\mathrm{v}$ sobě zahrnují základní principy a zásady kvalitní interpretace (souhrn $v$ tab. 1).
9 BECK, Larry a CABLE, Ted. Interpretation for the $21^{\text {st }}$ century: fifteen guiding principles for interpreting nature and culture. Champaign, III: Sagamore publishing, 2002, s. 204.

10 PTÁČEK, Ladislav a RÜŽıČKA, Tomáš a kol. Jak pře(d)kládat svět: základy dobré interpretace. Brno: Nadace Partnerství, 2012, s. 11. 11 Ibidem, s. 38.

\begin{tabular}{|l|l|l|}
\hline Prvek v návrhu expozice & Princip interpretace & Komentáŕ \\
\hline $\begin{array}{l}\text { Pozvání pravěkého lovce } \\
\text { do venkovní expozice }\end{array}$ & Osobní rovina & $\begin{array}{l}\text { Vložení osobnosti lovce přináší osobní rovinu } \\
\text { do expozice a vytváří príběh, který pomǔže } \\
\text { návštěvníkưm expozici více přibližit. }\end{array}$ \\
\hline $\begin{array}{l}\text { Prvek časová osa } \\
\text { v mlatové stezce }\end{array}$ & Analogie & $\begin{array}{l}\text { Tím byl vložen do expozice princip analogie, která } \\
\text { pomúže návštěvníkům porovnat přiběh s něčím, } \\
\text { co znají z osobního života. }\end{array}$ \\
\hline $\begin{array}{l}\text { Prvek skulptura - } \\
\text { pưvodní terén }\end{array}$ & $\begin{array}{l}\text { Nahlížení na místo } \\
\text { ziného úhlu } \\
\text { pohledu }\end{array}$ & $\begin{array}{l}\text { Díky skulptuře je originálně odkryta skrytá } \\
\text { vrstva místa a návštěvníkovi je nabídnuto } \\
\text { nahližení na dané místo z jiného úhlu pohledu. }\end{array}$ \\
\hline $\begin{array}{l}\text { Prvek lovci mamutů } \\
\text { a drobných zvírat }\end{array}$ & Prožitek & $\begin{array}{l}\text { Touto aktivitou se do expozice vloží prožitek, } \\
\text { který nám pomǔže vtáhnout návštěvníka do děje. }\end{array}$ \\
\hline Prvek pravěké sídliště & Porovnání & $\begin{array}{l}\text { Rozdílné typy stanů vnášejí do expozice přirovnání } \\
\text { pro porovnání charakteristik dvou věcí. }\end{array}$ \\
\hline Prvek pískoviště & Osobní prožitek & $\begin{array}{l}\text { Tento prvek zprostředkovává návštěvníkovi osobní } \\
\text { prožitek. Mǔže si vyzkoušet práci archeologa } \\
\text { a zároveň má možnost odnést si z lokality něco na } \\
\text { památku. }\end{array}$ \\
\hline $\begin{array}{l}\text { Prvek kresba na mamutím } \\
\text { klu na oplocení }\end{array}$ & Probouzení fantazie & $\begin{array}{l}\text { Tento prvek pomůže vyprovokovat návštěvníka } \\
\text { k premýšlení a k probuzení fantazie. }\end{array}$ \\
\hline
\end{tabular}

Tab.1. Souhrn navrhovaných prvků a jejich edukační význam. 
Vnitřní expozice je uvedena výpravným filmem, který popisuje klíčové prvky expozice (historii výzkumu paleolitických lokalit pod Pálavou, člověka a krajinu doby ledové, lovecké strategie a každodenní život lovců mamutů, jejich pohřební rituály, umění). Na závěr filmu vystupuje fiktivní postava lovce mamutů a pozve návštěvníky do své zahrady. Vstup do zahrady představuje světlík, který z vnitřku budovy láká návštěvníka k nahlédnutí. Příběh lovce mamutů byl vybrán na základě definice cúlové skupiny - rodiny s dětmi - a zároveň přibližuje osobnost lovce. Vložení osobnosti lovce přináší osobní rovinu do expozice a vytváří příběh, který pomůže návštěvníkům expozici více přiblížit.

\section{Prvek časová osa v mlatové stezce} (obr. 1, č. 2)

Návrh venkovní expozice počítá se světlíkem jako vchodem do venkovní expozice. Světlíkem projde návštěvník na mlatovou stezku, která tvoří osu venkovní expozice. Do mlatové stezky jsou vnořeny dřevěné hranoly z modřínového dřeva, na kterých jsou prolisy s letopočty. Letopočty označují významné události - vynález parního stroje, vynález knihtisku, počátek českého státu, narození Ježíše Krista, počátky budování pyramid až po letopočet osídlení lovci mamutů. Hranoly jsou umístěny poměrově, aby byla zřetelná hloubka času, ve které lovci žili. Stezka zároveň využívá terénní modelace svahu, kdy hranoly časové osy jsou na rovině a po posledním údaji se stezka volně láme do svahu a návštěvníkovi se objeví další části expozice. Tento prvek formou přirovnání zobrazuje těžko uchopitelnou představu o hloubce času, jež nás dělí od lidí, kteří na tomto území žili. Tím byl vložen do expozice princip analogie, která pomůže návštěvníkům porovnat příběh s něčím, co znají z osobního života.

\section{Prvek lovci mamutů a drobných zvírat} (obr. 1, č. 3)

Další část expozice vyvrací mýtus, že lovci mamutů se živili primárně lovem mamutů. Návštěvníci zde mají oštěpy a ma- kety zvířat, která tvořila jídelníček pravěkého lovce (kromě mamutů jsou zde také makety soba, vlka, lišky, zajíce a malých hlodavců. Návštěvníci je mohou lovit oštěpem, který je kopií historického nástroje.

\section{Prvek skulptura - původní terén} (obr. 1, č. 4)

Skulpturální prvek působí na jedné straně jako výtvarný objekt a na druhé straně připomíná, jak vypadal terén před sedimentací spraší. Skulpturální objekt tvoří tyče stejné délky, pomyslné hloubkové sondy, které rozmístěny v rastru $2 \times 2$ m vynášejí terén zpod spraší na povrch. Prvek je vysvětlen a rozkreslen na horizontální informační tabuli. Prvek vzbuzuje představivost a zároveň vnáší výtvarné řešení do prostoru venkovní expozice. Díky skulptuře je originálně odkryta skrytá vrstva místa a návštěvníkovi je nabídnuto nahlížení na dané místo z jiného úhlu pohledu. Touto aktivitou se do expozice vloží prožitek, který nám pomůže vtáhnout návštěvníka do děje.

\section{Prvek pravěké sídliště (obr. 1, č. 6)}

Pravěké sídliště je situováno ve spodní části venkovní expozice a je tvořeno dvěma stany s dispozicí vycházející z reálného půdorysu pravěkého sídliště. Jeden stan je experimentální, postaven metodami vycházejícími ze současných poznatků pravěkého stavitelství, druhý má stejnou konstrukci, ovšem tvořenou nejnovějšími materiály (karbonová vlákna). Tento stan bude přístupný návštěvníkům a budou zde probíhat ukázky jako štípání kamene, příprava hlíny na keramiku, rozdělávání ohně. Rozdílné typy stanů vnášejí do expozice prvek přirovnání, návštěvník může prozkoumat materiál používaný v minulosti a soudobé materiály. Na použití nejnovějších materiálů bude odkazovat také popis expozice, který charakterizuje lokalitu jako Silicon Valley gravettienu.

Prvek pískoviště (obr. 1, č. 8)

Navržené pískoviště ve spodní části expozice $\mathrm{v}$ sobě nese dvě roviny přirovnání. Pí- 
Obr. 1. Schéma navrhované expozice (autori: Lucie Breuerová, Monika Martišková, Daniel Mašín, Veronika Netolická, Marie Novotná, Daniela Plandorová, Tereza Poláčková, Helena Vrablcová). 1. Budova archeoparku. 2. Východ světlíkem a mlatová cesta

s prvkem časová osa. 3. Prvek lovci mamutů a drobných zvířat. 4. Prvek původní terén. 5. Prvek otisky listů vegetace gravettienu. 6. Prvek pravěké sídliště. 7. Zázemí pro workshopy. Prvek dětské pískoviště. 9. Východ $z$ expozice. 10. Společenstvo kvetoucí louka.

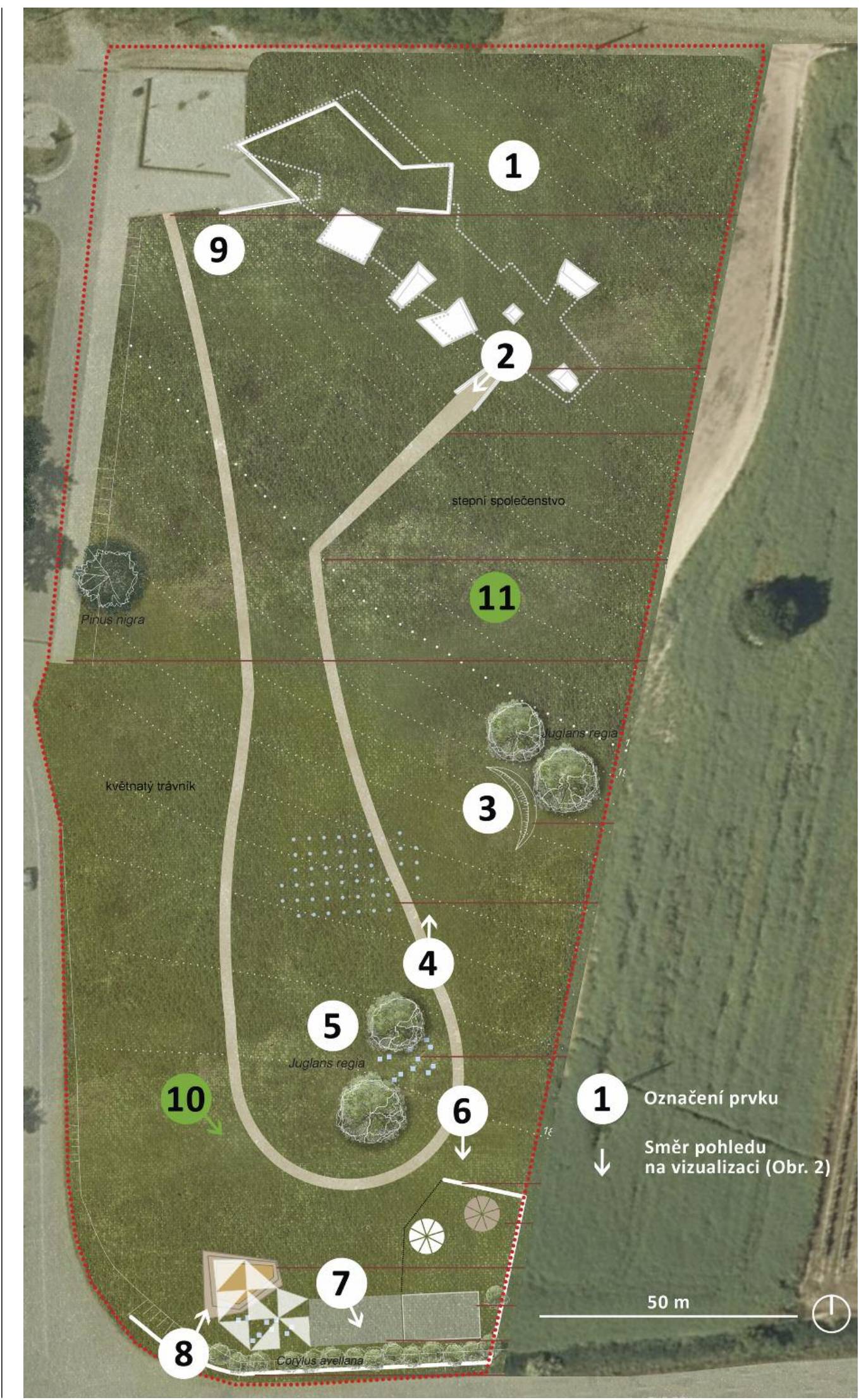

11. Společenstvo stepní. 

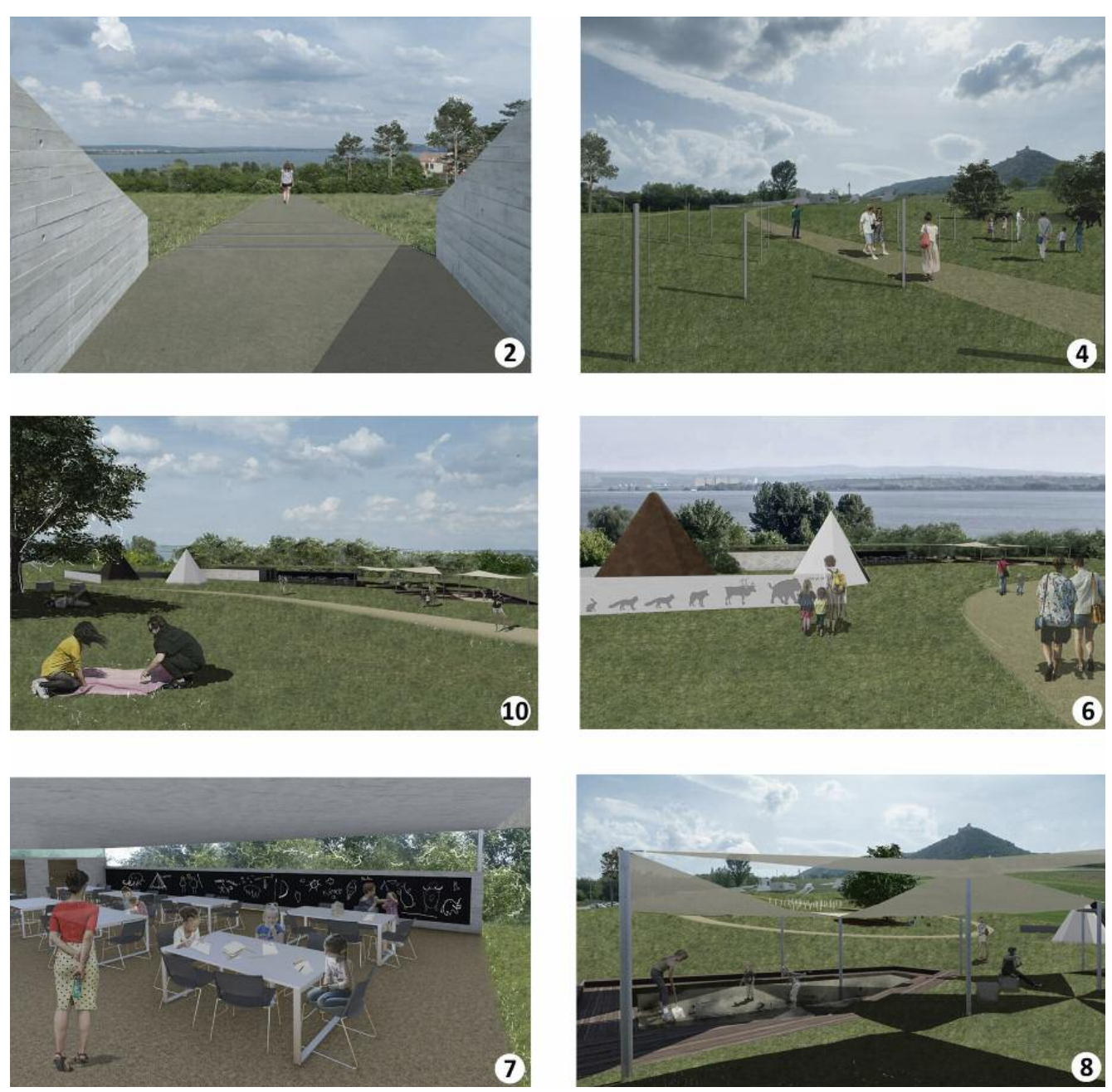

Obr. 2. Vizualizace návrhu venkovní expozice (autoři: Lucie Breuerová, Monika Martišková, Daniel Mašín, Veronika Netolická, Marie Novotná, Daniela Plandorová, Tereza Poláčková, Helena Vrablcová).

2. Vchod do venkovní expozice s mlatovou cestou s dřevěnými hranoly označující důležité letopočty. 4. Skulptura původní terén, ocelové tyče - pomys/né sondy, které přenášejí rovinu pưvodního povrchu na současný terén. 10. Pohled z květnatého trávníku v dolní části areálu směrem ke stanům, pískovišti a zastřešenému zázemí expozice. 6. Prvek pravěké sídliště. 7. Zastřešené zázemí dílny. 8. Hrací plocha s pískovištěm.

skoviště je tvořeno dvěma odsazenými dřevěnými platformami, které evokují archeologickou terénní sondu a stratigrafii vrstev. Dno pod pískem je modelováno do tvarů mamutích kostí, části „,kostí" jsou také volně ložené a děti je mohou celé vyhrabat a odnést. Tento prvek zprostředkovává návštěvníkovi osobní prožitek. Mưže si vyzkoušet práci archeologa a zároveň má možnost odnést si z lokality něco na památku.

\section{Prvek interpretace kresby} na mamutím klu

Jedním z nejznámějších artefaktů je kresba na klu. Dle současných interpretací se jedná bud' o první mapu, nebo o obraz krajiny. Tento motiv využívá část oplocení z pohledového betonu, umístěná u př́ijezdové cesty naproti autobusové zastávce. Návštěvník má „mapu“ přímo před sebou 


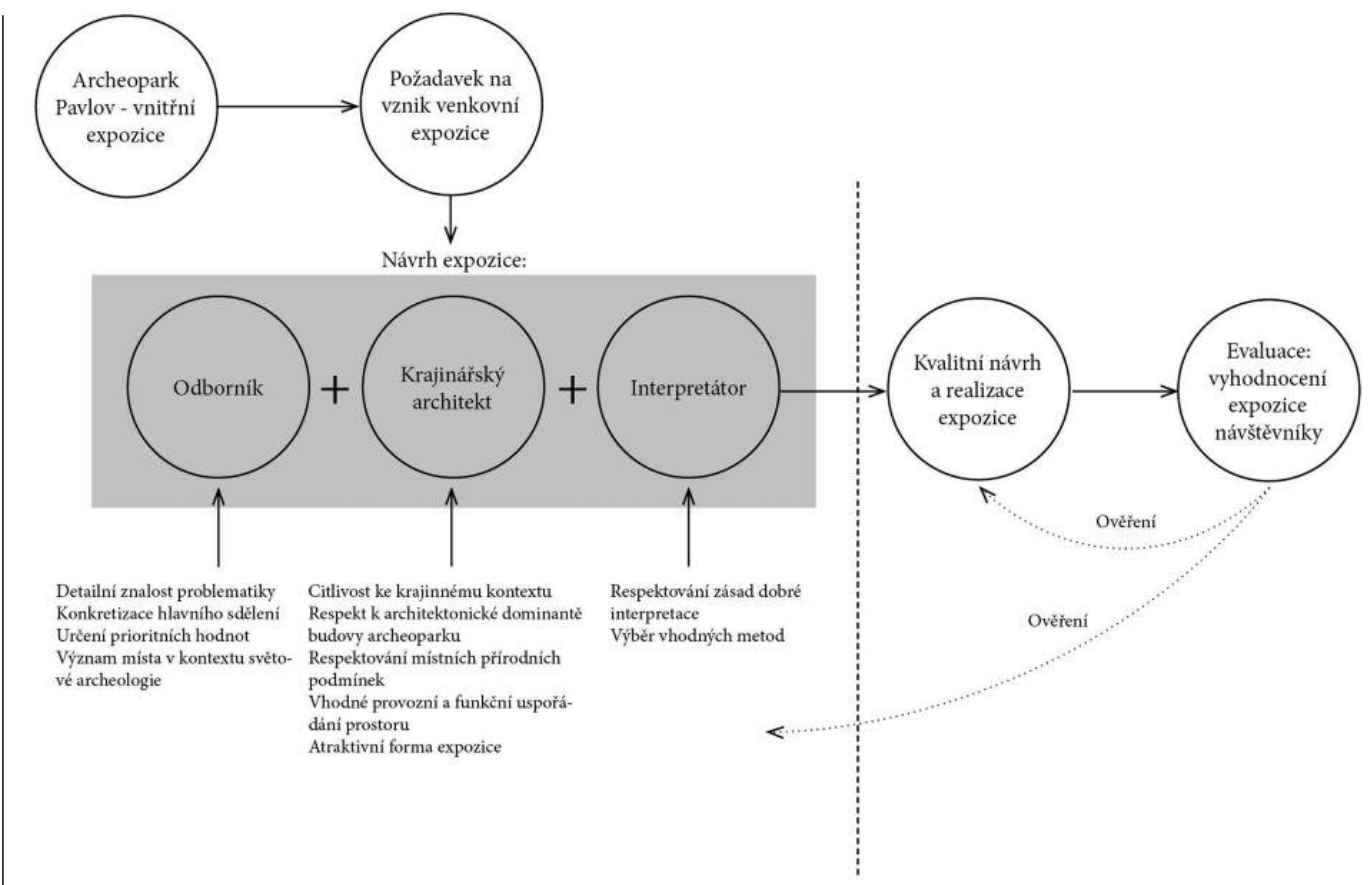

Obr. 3. Principy navrhování (autor: Daniel Matějka).

spolu s obrazem Děviček a Pálavy, má čas si ji prohlédnout a zamyslet se nad jejím významem. Tento prvek pomůže vyprovokovat návštěvníka $\mathrm{k}$ přemýšlení a k probuzení fantazie.

\section{Vegetační úpravy}

Nedílnou součástí návrhu jsou vegetační úpravy plochy. Vzhledem ke stávajícím klimatickým (a zejména mikroklimatickým) podmínkám návrh nepočítá s větším uplatněním vegetace gravettienu. Navrhované dřeviny navazují na dřeviny uplatňující se v kulturní krajině v okolí Pavlova (ořešák královský) a na parkové ploše u Archeoparku (borovice černá, resp. borovice lesní). Areál je rozdělen do dvou sekcí s ohledem na prírodní poměry. Vrchní, suchá část je tvořena stepními společenstvy vyskytujícími se na vápnitém podkladu v Pavlovských vrších, spodní, živnější část bude tvořena květnatým trávníkem. V exponovaných částech bude louka sečena, aby trávník snesl sešlap.

Stromy budou rozmístěny solitérně, aby prostorová struktura odpovídala době pa- leolitu. Použit bude ořešák královský (Juglans regia) zavětvený až $\mathrm{k}$ zemi. V horní části u cesty bude vysazena solitérně borovice lesní (Pinus silvestris). Ta vizuálně propojí přilehlý „lesopark“, vodoteč a venkovní expozici archeoparku. $V$ dolní části pozemku bude vysazena líska (Coryllus avelana), která odcloní vizuálně negativní Yachtclub.

Zelená extenzivní střecha bude pojednána přírodě blízkým způsobem druhy stepního společenstva, osázena druhy rostlin, které se ted' vyskytují $\mathrm{v}$ tundře a mohly se eventuálně vyskytovat $\mathrm{v}$ tundře $\mathrm{v}$ období paleolitu. Např́klad druhy, které se vyskytují v tundře na vápnitém podkladu. Mohly to být různé druhy lišejníků, třeba pukléřka sněžná (Flavocetraria nivalis). Dále silenka bezlodyžná (Silene acaulis), mochna (Potentilla elegans), kuřička polární (Minuartia arctica), skalenka poléhavá (Loiseleuria procumbens). A další druhy, jež se celkem běžně vyskytují $v$ tundře: suchopýry, šicha oboupohlavná, rdesno hadí kořen, rojovník bahenní, kyhanka sivolistá a další. 


\section{Principy navrhování}

Vznik kvalitní venkovní expozice, které bude návštěvník rozumět a pochopí její sdělení, je podmíněn otevřenou spoluprací krajinářského architekta, odborníka na danou problematiku a interpretátora. Odborník do procesu tvorby přináší detailní znalost problematiky, určuje prioritní hodnoty předmětu expozice, pomáhá konkretizovat hlavní sdělení expozice a pomáhá vsadit význam místa do kontextu světového měřítka $-\mathrm{v}$ př́padě Archeoparku Pavlov se může jednat například o sdělení, že význam místa z hlediska historie se dá prrirovnat $\mathrm{k}$ současnému Silicon Valley. Krajinářský architekt navrhuje uspořádání prostoru tak, aby respektoval krajinné zázemí expozice, byl v souladu s architektonickou formou budovy archeoparku a zároveň nabídl atraktivní formu expozice. Při procesu tvorby expozice je nezbytné respektovat zásady dobré interpretace uvedené výše.

Po realizaci expozice je nezbytné reflektovat její vliv na návštěvníky, ověřovat jak kvalitu jednotlivých prvkủ expozice a jejich interpretační hodnotu, tak i fungování prostoru jako celku.

\section{Závěr}

Při návrhu venkovní expozice Archeoparku Pavlov byly použity myšlenky a principy kvalitní interpretace, které jsou popsány v úvodní části. Jednotlivé prvky expozice v sobě tyto principy zahrnují a je vysvětleno, co přesně mají návštěvníkovi zjevit. Díky propojení architektonického návrhu, který přináší do prostoru citlivé rozmístění jednotlivých prvků expozice originálně výtvarně řešených, a samot- ného obsahu expozice založeného na zásadách dobré interpretace vzniká zajímavý experiment. Zda je návrh kvalitní a opravdu návštěvníkům předává hlavní klíčové sdělení, které bylo definováno, by potvrdila pouze realizace návrhu a následné vyhodnocení vlivu expozice na návštěvníky.

\section{Použité zdroje}

ALDRIDGE, Don. Principles of countryside interpretation and interpretive planning. Edinburgh: H.M.S.O. for Countryside Commission for Scotland, Countryside Commission, 1975, s. 32.

BECK, Larry a CABLE, Ted. Interpretation for the $21^{\text {st }}$ century: fifteen guiding principles for interpreting nature and culture. Champaign, Ill.: Sagamore publishing, 2002, s. 204.

HAM, Sam. Interpretation - Making a Difference on Purpose. Golden. Colorado: Fulcrum publishing, 2013, s. 290.

PTÁČEK, Ladislav a RUீŽIČKA, Tomáš a kol. Jak pře(d)kládat svět: základy dobré interpretace. Brno: Nadace Partnerství, 2012, s. 123.

SVOBODA, Jiří. Dolní Věstonice - Pavlov. Praha: Academia, 2016, s. 399.

TILDEN, Freeman. Interpreting our heritage. Chapel Hill: University of North Carolina Press, 1977, s. 212.

\section{Poděkování}

Autoři děkují Mgr. Petru Kubínovi z Regionálního muzea v Mikulově a Mgr. Martinu Novákovi, Ph.D., z Archeologického ústavu AV ČR, Brno, za cenné připomínky a korektury. 